\title{
Celebrity, Class and Gender in Spain. An Analysis of Belén Esteban's Image
}

\author{
Mercè Oliva
}

Department of Communication, Universitat Pompeu Fabra, Barcelona, Spain

merce.oliva@upf.edu

\begin{abstract}
Belén Esteban is the most significant example in Spain of a new kind of celebrity that cannot be linked to traditional definitions of talent and work. She is often talked about with contempt, used as a synonym of 'trash TV' and seen as evidence of the loss of meritocratic values in Spain. This article analyses how her celebrity image provides a stage for political struggle that embodies current Spanish tensions regarding class and gender. Belén Esteban's image offers a symbolic battleground upon which the debates about the place and roles of working-class women in Spanish society are acted out. In order to fulfil this aim, this paper analyses two stages upon which these debates are enacted. Firstly, there are the discourses of disgust surrounding her in the Spanish media. Secondly, there are her TV appearances in Sálvame Diario and Sálvame Deluxe, two celebrity gossip programmes in which she works and in which her celebrity image is mainly constructed.
\end{abstract}

Keywords: Belén Esteban; working-class women; celebrity; class; gender

\section{Introduction}

She wears clothes that could have been bought in a street market. Her makeup hardly ever lasts because her tears smudge it. When she talks she finds it difficult to conjugate some verbs. And her manners are vulgar. Nevertheless, she is quite a star. (Galaz 2010)

In this excerpt from the Spanish newspaper El País, the author expresses puzzlement about the emergence of a personality who combines things she considers to be 
contradictory: being a celebrity yet being tasteless, emotionally excessive, uneducated and vulgar. In this regard, she points to a transformation in celebrity culture and the rise of what she perceives to be a different kind of celebrity. Although this quote may seem to be referring to British celebrities such as Jade Goody or Kerry Katona, it actually refers to Belén Esteban. Belén Esteban is the most significant example in Spain of the so-called 'famosillos' (literally meaning 'little celebrities', in a derogatory sense), celebrities who are perceived as 'lacking some of the fundamental discourses of the success myth, largely the emphasis on work and traditional conceptions of talent' (Holmes 2004, p. 119) ${ }^{1}$. She became well-known in 1998 for having a love affair with a famous Spanish bullfighter (Jesús Janeiro, aka Jesulín de Ubrique) and since then she has attracted extensive media exposure.

Belén Esteban has been a celebrity for almost 15 years and for the last four years she has appeared for approximately 20 hours a week on the main Spanish commercial TV channel, since she works as a collaborator in two celebrity gossip programmes: Sálvame Diario and Sálvame Deluxe (Telecinco 2009-). Her TV appearances attract millions of viewers; since $1999^{2}$ she has regularly appeared on the cover of celebrity gossip magazines such as ¡Hola!, Lecturas and Diez Minutos;she has been on the cover of Interviu (a popular men's magazine ${ }^{3}$ ) four times, and she has been hired to endorse products such as kitchenware (San Ignacio), shoes (Furiezza), a telecommunications company (MásMóvil) and a bingo website (Yo Bingo). Nevertheless, she also provokes comments of disgust and contempt: she is often used as a synonym of trash TV and she is seen as evidence of the loss of meritocratic values in Spain in terms of fame.

Richard Dyer (1986, 1998, p. 34-85) argue that stars embody the tensions and debates of their time and that 'stars matter because they act out aspects of life that matter to us' (Dyer 1986, p. 19). Although stars and celebrities have different cultural 
meanings and value, celebrities can also be understood as figures that personify a broad range of concerns and dialectics of the society from which they emerge (Negra \& Holmes 2008). The main aim of this paper is to analyse how Belén Esteban's celebrity image acts as a stage for political struggle that embodies current Spanish tensions regarding class and gender. Belén Esteban's image provides a symbolic battleground upon which the debates about the place and roles of working classes (and specifically working-class women) in Spanish society are acted out.

These debates are held in two overlapping stages or areas that will be analysed in this paper. First, there are the discourses about her published in the Spanish media. In these discourses, Belén Esteban acts as a 'lightning rod' (Negra and Holmes 2008) for a range of concerns relating to meritocracy, commercialisation and the dumbing-down of the Spanish media (television and press), the loss of cultural hierarchies, and a decline in Spain's democracy and political system. What I would like to do here is to explore how these topics become entangled in the discursive construction of Belén Esteban.

Secondly, there are Belén Esteban's appearances on Sálvame Diario and Sálvame Deluxe. On the one hand, Sálvame strategically includes and exploits a number of working-class traits in the construction of Belén's image, valuing her 'otherness' and her apparent distance from the middle-class. In doing so, it appears to challenge the social and symbolic position and value assigned to the working classes in Spain. On the other hand, Sálvame also introduces elements of restraint by imposing a disciplinary gaze upon her and limiting her agency and power within the programme.

Compared to English-speaking countries, which have a longer tradition of research into stars and celebrities, celebrity culture has received little academic attention in Spain. This article seeks to explore contemporary Spanish celebrity culture through one of its paradigmatic figures, thus enabling the Spanish context to enter the dialogue 
of celebrity studies. In order to do this, the article necessarily uses concepts developed in relation to other national contexts - the British one in particular - and part of my interest here is in testing how they apply to other national contexts. As I will demonstrate, the discourses surrounding working-class female celebrities in the UK have similar counterparts in Spain. This similarity points towards the existence of a widespread discourse that expresses specific class and gender prejudices through celebrity culture.

\section{From ¡Hola! to Sálvame. Contemporary celebrity culture in Spain}

In order to understand the emergence of Belén Esteban as a celebrity, this section will summarise the development and main traits of contemporary Spanish celebrity culture and its differences with regards to traditional discourses on fame.

Spain has a long tradition of celebrity gossip media. The magazine $; H o l a !$ ('Hello!') appeared in 1944; Lecturas ('Readings'), Semana ('Week'), and Diez Minutos ('Ten Minutes') became gossip magazines in the mid-1960s and Pronto ('Early') appeared in 1972 (Gómez Mompart 1992, Falcón 1998, Lamuedra 2004). All these magazines are still published today. The celebrities that have appeared traditionally in these magazines are European royal families and aristocracy as well as Spanish show business stars (cinema and television actors and actresses, singers, bullfighters and beauty queens). These magazines focus exclusively on their 'private' lives: love affairs, marriages, births, baptisms and homes. Their features depict celebrities in a favourable light, with flattering pictures and commentaries, portraying fame as a 'natural' process by which the most attractive, young, rich and powerful individuals gain media visibility (Gallego 1990, p. 112-113, 117-123). This is a trait that traditional Spanish celebrity culture shares with English-speaking countries such as the US (Gamson 1994, 9. 15-39). 
Gossip TV programmes appeared much later, in the mid-1990s, after the end of the public broadcasting monopoly. A number of these programmes were very similar to the traditional gossip magazines in terms of focus and treatment, while others broke with this tradition and marked a turn in Spanish celebrity culture.

Firstly, there was Qué Me Dices! (a colloquial expression that means 'Say what!') (Telecinco 1995-1998). It was characterised by an ironic, detached discourse on celebrities (Lamuedra 2007, p. 29-30, Mercado Sáez 1999) and started a trend similar to the one identified in the US and the UK by Joshua Gamson (1994, p. 40-55) and $\mathrm{Su}$ Holmes (2005) respectively. After this programme disappeared, Aquí Hay Tomate (literally meaning 'There is tomato here', a colloquial expression used in the context of gossip to refer to some scandalous or juicy story) (Telecinco 2003-2008) took its place. This was a very influential programme that took the traits of Qué Me Dices! to an extreme level: teasers that used big, sensationalistic headlines, dramatic music, a protracted rhythm, features that attacked and mocked celebrities, the use of mostly paparazzi images (but also some interviews with minor celebrities). Because of its confrontational attitude towards celebrities, most of the well-established Spanish celebrities refused to answer any of the programme's questions in press conferences and premieres. Aquí Hay Tomate became the epitome of 'trash TV' in Spain and a number of its characteristics can still be found in several celebrity gossip TV programmes.

At the same time, new gossip magazines appeared in the Spanish market that shared this ironic discourse and detached attitude towards celebrities: Qué Me Dices! (1995-), Cuore (2006-) and In Touch (2006-) ${ }^{4}$.

Tómbola ('Raffle') (Canal 9 1997-2004) was also very influential (Lamuedra 2007, p. 29-30, Mercado Sáez 1999). In Tómbola, five gossip journalists interviewed several celebrities every week and it became recognised for an aggressive tone and its 
sensationalistic content (see Mercado Sáez 1999 and Cáceres 2000). In spite of the programme's harsh attitude towards its guests, minor and fairly major celebrities in need of media exposure and money agreed to be interviewed on the programme. This same formula was repeated later in several gossip programmes aired at prime time: Salsa Rosa ('Pink Sauce’) (Telecinco 2002-2006) and, ¿Dónde Estás Corazon? ('Where are you, sweetheart?') (Antena 3 2003-2011).

These new programmes and magazines also featured what were perceived in Spain as new kinds of celebrities ${ }^{5}$. Firstly, these were 'celebrities by relationship': people that became well-known because they were a celebrity's partner or relative (sons, daughters, sibling or parents) (Lamuedra 2007, p. 29). Some examples of these are: Raquel Mosquera, Rocío Carrasco and Antonio David Flores, all related to Rocío Jurado (a famous singer) and Pedro Carrasco (a boxer). Secondly, there were reality TV celebrities. Big Brother premiered in Spain in 2001 and the celebrities that emerged from it - and from other reality game shows that flourished after it - fit into this new media landscape that needed to be fed with new personalities such as María José Galera, Sonia Arenas, Rafa Mora and Almudena Martínez. Finally, the so-called freaks or frikis (the Spanish adaptation of the English term): for example, mediums (Paco Porras and Aramis Fuster) and 'Z-list' singers (Tamara/Yurena and Leonardo Dantés). In Spain, these three kinds of celebrities are encompassed by the category of 'famosillos'.

As a consequence of such shifts in the celebrity gossip media's tone, content and featured personalities, there is currently a perception of a profound decline in Spanish celebrity culture, a perception very similar to that pointed out by Holmes (2004) in the UK.

Both Belén Esteban and Sálvame emerge from this context. In order to familiarise Anglo-American readers who do not know Belén Esteban and Sálvame, in 
the next paragraphs I will summarise Belén Esteban's life and Sálvame’s main traits.Belén Esteban's life is usually told as follows ${ }^{6}$. She was a working-class girl from Madrid who became a celebrity when she started a love affair with the bullfighter Jesús Janeiro. In 2000, they had a daughter (Andrea). A few months later, Belén broke up with him because of his infidelities and opposition from Jesús' family based on the economic differences between them. After the break-up, she was regularly interviewed by gossip magazines and TV programmes, and a few years later she began working regularly on one of them (El Programa de Ana Rosa, Telecinco 2005-) as a 'collaborator'. In 2009 she started working in Sálvame Diario and Sálvame Deluxe, and since then Belén's public image has been very much associated with this programme. In 2009-2010 she achieved the peak in her popularity and career. In 2009 she underwent a physical makeover that attracted a lot of attention: the issue of Lecturas featuring her new look sold out and Sálvame achieved the best audience ratings of the season. But in 2011 she began a personal and professional decline that ended up in a 3month retirement beginning in September 2012. When she came back to Sálvame she publicly admitted having a drug addiction. Some months later, in April 2013, after a big argument with her co-workers in Sálvame Deluxe, she retired again.

Sálvame Diario is, precisely, the programme that continues the tradition established by Qué Me Dices! and Aquí Hay Tomate. It is a daily four-hour celebrity gossip programme broadcast in the afternoon. Sálvame Deluxe follows Tómbola's traits and is broadcast on Fridays at prime time. The host of both programmes is Jorge Javier Vázquez (he was also the host of Aquí Hay Tomate) and their main contributors/collaborators are gossip journalists (Lydia Lozano and Maria Patiño), a celebrity manager (Kiko Matamoros), a former Big Brother contestant (Kiko 
Hernández) and several 'celebrities by relationship' (Belén Esteban, Rosa Benito and Raquel Bollo).

Sálvame as a gossip programme has unique traits that make it stand out from its contemporaries. Firstly, it has an ironic, harsh tone with regard to celebrity culture.

Secondly, it regularly shows the 'backstage' of the programme. The camera goes behind the set and makes the structure of the stage features visible: the cameras, the travelling rails, the corridors, the dressing rooms and even the toilets of Telecinco. The programme's director and the production team are also shown, and the host regularly talks and discusses the programme's content and structure with them. In doing this, the programme presents itself as transparent and sincere because it appears to show its own manufacturing processes. Thirdly, it blurs the distinction between journalists and celebrities: the collaborators usually argue angrily and some of them (even some journalists) have been interviewed on the programme regarding their private lives. Finally, it has a 'free' structure, with no clearly defined sections. Actually, the programme mixes celebrity gossip with other temporary sections featuring beauty contests, makeovers and even a talent show with the programme's collaborators as contestants.

Having explained the context of contemporary Spanish celebrity culture and the place of Belén Esteban and Sálvame within it, in the following sections I will analyse Belén's image and the debates and tensions that she embodies regarding class and gender in Spain.

\section{Fea, inculta and barriobajera $^{7}$ : discourses of disgust}

The main aim of this section is to explore the discourses of disgust surrounding Belén Esteban published in the Spanish media. As has been said in the introduction, this is one 
of the fields where the debates on working-class women's place, role and worthiness are acted out.

Belén Esteban is not an isolated case from an international perspective. In the last decade, the UK and the US have produced similar celebrities, such as Jade Goody and Kerry Katona (UK), and Snooki or JWoww (US). This kind of celebrity has attracted the attention of scholars such as Anita Biressi and Heather Nunn (2005, p. 144-155); Su Holmes (2004, 2009); James Bennett and Su Holmes (2010); Diane Negra and Su Holmes (2008); and Imogen Tyler and Bruce Bennett (2010). Their work has focused on the disgust and contempt aroused by these celebrities and the debates and tensions they embody with regard to class and gender. Imogen Tyler and Bruce Bennett (2010, p. 376) argue that 'celebrity is understood as a distinctly disciplinary sphere of social life, a class pantomime through which the establishment of social hierarchies and processes of social abjection (qua punishment for sexual and social transgression) are acted out figuratively'.

Celebrity culture is just one sphere in which working-class women are stigmatised and 'disciplined'. Steph Lawler (2004, 2005, 2008, p. 122-142), Beverly Skeggs (2004, p. 96-118) and Imogen Tyler (2008) argue that working-class women synthesise most middle-class anxieties, since the later construct their identity and worth in opposition to the characteristics of the former: 'working classness forms the constitutive outside to middle-class existence' (Lawler 2005, p. 431). Working-class women are constructed as offensive individuals that provoke nothing but disgust. According to Skeggs (2004, p. 102-103), Lawler (2004, 2008) and Tyler (2008), disgust is a central feature in the make-up of middle-class identity. These scholars show how class is emotionally mediated through disgust, foregrounding the importance of emotion in class making. Disgust, defined by the Oxford dictionary as a 'feeling of revulsion or 
strong disapproval aroused by something unpleasant or offensive', is a 'permanently distanciating' (Skeggs 2004, p.102) feeling that draws lines between individuals. It is a way of naturalising social divisions and creating a consent that maintains the social order. In fact, Lawler (2005) calls the middle-classes 'disgusted subjects'.

Working-class women are usually despised for being vulgar and unruly, for eating and drinking excessively and lacking discipline and self-control. Their physical appearance is also the focus of these discourses of disgust: as the work of Lawler, Tyler and Skeggs show, they are regularly caricaturised as overweight women with big breasts that wear tight, flashy clothes and too much make-up and jewellery. All these arguments have to do with perceptions of excess (Skeggs 2004, p. 99-105) and an ‘inability to perform femininity correctly' (Tyler and Bennett 2010, p. 381), since their work on their body and appearance to maximise their femininity is thought to be too visible and sexualised. Moreover, Lawler (2004, p. 115-118) identifies two more arguments regularly used in the media to stigmatise and ridicule working-class women: their ignorance, lack of education and their 'irresponsible' motherhood. Moreover, Tyler and Bennett's work (2010) shows that the expressions of disgust targeted at working class female celebrities are very similar to those targeted at anonymous working class women.

Skeggs, Lawler and Tyler argue that using taste, knowledge and behaviour as arguments to despise both celebrity and anonymous working class women is a way of concealing the true argument against them: class. Although they are seemingly attacked because of their individual traits, the main argument against them is social. For these scholars, although class seems to have lost its centrality in sociological research, it is still relevant to understand social relations. 
In Spain, Belén Esteban has also aroused discourses of contempt and disgust that use the very arguments identified in the UK. In comedy programmes, Internet forums and newspaper opinion features, she is regularly described as ordinaria (meaning 'ordinary' but also 'vulgar', pejoratively), chabacana ('tasteless', also pejorative), inculta ('uncultivated' or 'uneducated') and barriobajera (literally meaning 'from a low neighbourhood', this word has a pejorative meaning and is used to describe a person who is uneducated, has no manners or taste, is loud, vulgar and behaves or speaks scandalously). The quote at the beginning of this article is a good example of this kind of discourse.

Several expressions of disgust also focus on her body and face, which are heavily scrutinised: she is attacked for being fea ('ugly') and repulsiva ('repulsive') and her physical degradation is always pointed out and seen as evidence a life of excess and drug abuse. Even after her makeover, she has been identified as an example of 'abject plastic surgery' (a term used by Fairclough 2012):

What did she do to her face? (Vertele 2012)

God, what an awful woman! Ugly, ugly... and ugly. She is the woman of a thousand faces. And her face will get deformed again as always. (Vertele 2012)

She has a scary face. The plastic surgery, the drugs and the Botox... (Vertele 2012)

Moreover, in caricatures of her she is usually portrayed as subhuman. For example, she has been pictured several times looking like a monkey in the popular satirical magazine El Jueves ${ }^{8}$ ('Thursday', 1977-) ${ }^{9}$, reinforcing her image as an uneducated, idiotic woman. It is also worth noticing that both caricatures represent her with a ponytail and large earrings, which are used in these images to represent her as a working-class woman. 
Exploration of the discourses aroused by Belén Esteban indicates that she is perceived as an acceptable target of loathing and condemnation. And it is precisely the idea that she is an 'undeserving recipient of wealth' (Tyler and Bennett 2010) that legitimises such harsh comments: she didn't move upward socially and economically by means of education or hard work and she has no talent that justifies her social position (elements present in the definition of achieved celebrity, Rojek 2001, p. 17-18). For example, a recent feature published in Vertele ${ }^{10}$ about how much money Belén Esteban earned from an interview on Sálvame provoked comments like these:

It is absolutely shameful that a person like this earns so much money just for telling lies, with the current crisis and the amount of unemployed people who don't have any money, although they are educated and have expertise. Unlike this 'lady', who has no education at all... (Vertele 2012)

$€ 30,000$ equals the monthly wages of 20 journalists that studied at university. I need say no more. (Vertele 2012)

The expressions of disgust explored so far express a perceived threat to the legitimacy, authority and power of the middle-classes and their values and culture. The idea behind these discourses is that she is in a social space (stardom) where she does not belong, since she does not have any legitimate talent, knowledge, taste or beauty. This same argument is at the core of some sketches in comedy programmes ${ }^{11}$ : the apparent contradiction that a working-class woman like Belén can also be a celebrity and be featured in celebrity gossip media.

In this respect, it is useful to take into account María Lamuedra's reception analysis of celebrity gossip media in Spain and the UK (Lamuedra 2005: 362-367). She noticed that the people she interviewed had two opposing views regarding Belén Esteban. On the one hand, middle-class people usually expressed disgust towards Belén 
and they used meritocratic values as an argument against her. On the other hand, the working-class people approved of Belén because she had taken advantage of an opportunity to better her social and economic position. By saying this they implied that there were not many opportunities for working-class people to achieve upward social mobility, denying that society gives everybody equal opportunities.

Moreover, as I said in the introduction, Belén also functions as a 'lightning rod' for a broad range of social, cultural and political concerns. For example, this was particularly visible in a debate in 2010. In September 2010, El País' Sunday magazine (El País Semanal) devoted its cover and main feature to her, in which her social impact was critically analysed. This triggered many letters of complaint (Pérez Oliva 2010). Interestingly, the main argument in most of these comments was that she should not be on the cover of the magazine at all.

Again, we can think of this debate as one related to the 'place' of workingclasses and popular culture: these letters were a reaction against her presence in a social and cultural space where she 'didn't belong'. First, because she is a celebrity - i.e. a 'feminine', 'banal' topic from the private sphere entering the 'masculine', 'serious' public sphere. In Spain, celebrity gossip media are very much gendered: magazines and TV programmes are called prensa rosa ('pink press'), which clearly connotes femininity, or prensa del corazón ('press of the heart'), because their content is mainly focused on celebrities' sentimental lives. These complaints connect with the idea of a feminisation of the public sphere, although it is not explicitly mentioned. As Thomas points out: 'feminisation results in cultural disqualification and relegation from the legitimate to the illegitimate sphere' (2011, p. 164). This claim of feminisation as a consequence of the incorporation of content conventionally gendered as feminine into 
traditionally masculine media and genres such as press and prime time TV can also be found in the UK (for example, see Moseley 2001, p. 32-33 regarding prime time TV).

Secondly, because she is a certain kind of celebrity, a famosilla opposed to the values of the middle-class. A celebrity like Penélope Cruz, for example, would not have stirred up this kind of reaction. Actually, in several of these comments one can identify a feeling of being under attack from some sort of invasion ${ }^{12}$.

Belén Esteban's cover in El País Semanal also provoked debates in Internet forums and blogs. Here, the discussion that took place on Antonio Muñoz Molina's $\operatorname{blog}^{13}$ is particularly interesting. In December 2010, he published this:

I would never ever have imagined that a photograph of Belén Esteban could appear on the cover of El País Semanal. Does nothing matter any more? (Muñoz Molina 2010)

Here, Muñoz Molina identifies the Belén Esteban cover as evidence of a decline in standards in El País, and even points to a more general decline in Spanish society. This post received 176 responses, all of them agreeing with Muñoz Molina. In this virtual debate, Belén is linked to broader concerns regarding the commercialisation of El País and Spanish journalism in general, the low cultural standards of Spanish society, the loss of meritocratic values (especially regarding the importance of education) and, finally, even the incompetence and corruption of Spanish politicians:

I do not understand how we have been able to create such a grotesque and devastating situation. (...) This situation is a true reflection of what ordinary Spanish people think and the values that are transmitted to Spanish society: the less you know, the further you will go. Thank God there will always be a minority of people who feel embarrassed by all of this and who refuse to follow this model. (Quesada 2010) 
This leads you to think that we have what we deserve. We have the press that we deserve, the politicians that we deserve, the television that we deserve, etc.

(Alarcon 2010)

Who watches her? The people with the lowest level of cultivation in Spain; and we give this kind of viewer the power to decide what popular culture is nowadays. And the rest of us look on, terrified at what is going on. (Elvira 2010)

The argument behind these comments is that Belén Esteban's success is proof of the low cultural, political and even moral standards of the majority of the Spanish population, which, at the same time, is understood as an explanation of the low standards of the Spanish media, society and democracy.

Moreover, all the comments are based on implied arguments: they do not explain why it is outrageous that Belén Esteban is on the cover of EPS, because for these readers it is obvious. Consequently, a shared middle-class identity is constructed and legitimised upon these implicit ideas, as well as the expression of shared disgust. Furthermore, in order to strengthen this joint identity and oppose themselves to what Belén Esteban and her supporters stand for, several comments contain explicit references to middle-class cultural capital (Bourdieu 1979). By doing so, the authors of these comments attribute to themselves a 'cultivated nature' traditionally ascribed to the middle-class, as opposed to the 'natural nature' of popular classes (Bourdieu 1984, p. 485-502). Here taste, cultural consumption and education are used as markers (and euphemisms) of class, and they are also the main arguments used to attack her and her fans.

This same link between Belén and a downward spiral in Spanish social values can be found in a number of opinion articles about her in the 'quality' press. For example, Josep Ramoneda (2010) sees her as a populist phenomenon that conveys a 'disdain for the elites'. Ramoneda acknowledges a link between Belén Esteban's success 
and a feeling of unrest in the Spanish population regarding politicians - because of their corruption, incompetence, and distance from the people. But he also implies that the real reason for her success is that the popular classes are easy to manipulate and seduce:

Her resources: yelling, crying, gesticulating, getting indignant, using vulgarity and tastelessness to create her style. They are repeated in a never-ending spiral (...). The power of simplicity and repetition is well-known. Eternal repetition of the same thing is an old technique for collective seduction. (Ramoneda 2010)

Here, we have to point to a gender bias, because it is assumed that the masses who are fascinated by Belén and easily manipulated are made up of women (as said in previous paragraphs, in Spain the celebrity gossip media are profoundly gendered).

Some of these ideas are synthesised in Ricardo Peregrina's artwork 'Belén in excelsis o Arriba la Esteban' exhibited in the Caceres Pop Art Festival in 2010 (Figure 1). This is a triptych in which Belén Esteban is portrayed as a Romanesque Maiestas Mariae $^{14}$. In the central panel she is seated on a throne while she is worshipped by three journalists on the right panel, and three women on the left. 
Figure 1: 'Belén in excelsis o ;Arriba la Esteban!', by Ricardo Peregrina

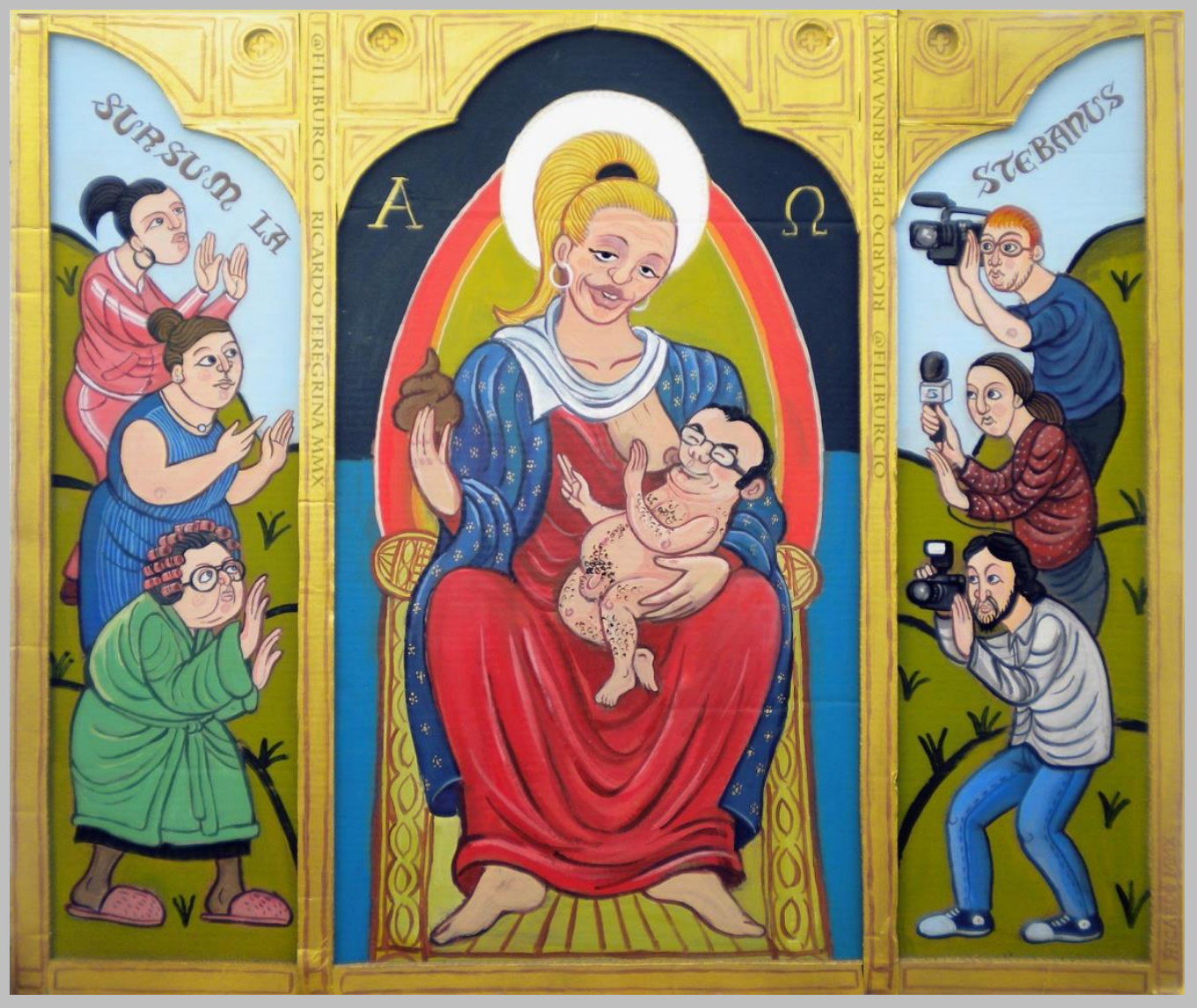

This artwork conveys the apparent opposition between the social position achieved by Belén as a celebrity and her low value as a 'cultural product'. On the one hand, Belén is worshipped by both the media and working-class women. Peregrina uses a religious metaphor here to depict celebrities' social role, an idea also developed by Chris Rojek (2001). On the other hand, the low cultural value of Belén is represented in the material on which the work is painted (cardboard) and the excrement that she is holding in her hand, which clearly point to the idea of 'trash TV', since in Spain this is usually related to 'shit'. Consequently, the humour of the piece is again built upon the representation of Belén in a place where she doesn't belong: here she is not represented as an undeserving recipient of wealth, but of attention and prestige.

Moreover, in Peregrina's work, gender and class are very significant. Belén is worshipped by three women that are portrayed with clear markers of working-classness: 
there are two marujas (a pejorative name to refer to middle-aged working-class women $^{15}$ ) and a choni (a pejorative name used to identify young working-class women; it is an equivalent to the British term chav). Moreover, these markers of class can also be found in Belén: she and the young woman on the left are wearing the same ponytail and earrings. It can be argued that the feminine, working-class character of Belén's fans also helps to identify her low cultural value.

This work also points to another interesting contradiction: one that is related to power. On the one hand, Belén is conveyed as a powerful personality, hierarchically superior to her audience and even the media. But at the same time, she is also exploited by the media: she is breastfeeding Jorge Javier Vázquez (the host of Sálvame), which points to the idea that she is being squeezed and used up by him. It is this very contradiction that is going to be explored in the next section.

\section{4. 'Belén, say something in English'. The contradictory discourses about Belén Esteban in Sálvame}

In order to fully understand Belén Esteban's celebrity image we also have to explore her appearances on Sálvame and its contradictory representation of her.

When Sálvame was first broadcast, Belén Esteban was already a celebrity and had created a public image with distinct features in which gender and class were central elements.

In her second appearance on television, an interview in Tómbola (2000) a few months after she had broken up with Jesús Janeiro, she presented herself as 'mother courage' and an abandoned woman, two roles that are still central to her contemporary image. In Sálvame, she usually talks about her daughter and attacks Jesús for being a bad father who never sees Andrea. Interestingly, one of her catchphrases is 'I kill for my 
daughter', underlying motherhood as her prime role. Her life's narrative is also gendered: she became famous thanks to a love affair with a celebrity and she has 'tried' to achieve happiness through traditionally feminine roles: motherhood and marriage. Furthermore, her appearances in Sálvame focus completely on her private life.

In the Tómbola's interview, she also explicitly stated several times that she was working-class:

Most of the press say that I am barriobajera. Ok, great. Am I barriobajera? Maybe I am. I live in a humble neighbourhood, but I have been the happiest person in such a humble neighbourhood.

In this quote we can already find two components that have been a part of Belén's public celebrity image since she appeared: on the one hand, she acknowledges that she is portrayed by the media as barriobajera, in other words, as uneducated, tasteless and vulgar. On the other hand, she incorporates these traits as a part of her identity, claiming that there is nothing to be ashamed of and that she is proud of her social identity.

Her public image is built upon a certain resistance to upward social mobility. Belén Esteban refuses to adopt the middle-class habitus to become respectable (see Lawler 1999) and she does this visibly. She performs a ‘dramatic realisation’ (Lawler 2008, p. 105-108) that underlines her working-classness and makes it visible. By doing so, she is proclaiming her 'otherness' in relation to hegemonic social groups ${ }^{16}$ and assigning worthiness to her class identity. In addition, she does so in a self-conscious manner, and with a defiant tone and attitude.

Moreover, Belén's resistance to social ascent is also made as regards physical space. For years, she refused to leave her working-class neighbourhood (San Blas, in Madrid). She maintains her childhood friends (she usually talks about Mariví) and in 2008 she married a bartender from her same neighbourhood. 
Sálvame also contributes to her image, strategically highlighting, celebrating and exploiting some traits traditionally used by the media to represent working-class women (seen in the previous section of this paper). In doing so, the programme offers a carnivalesque representation (Fiske 1989, p. 65-98) ${ }^{17}$, turning social hierarchies upside down and valuing the very traits that are traditionally despised. As Ramoneda's article shows (quoted in the previous section), Sálvame's celebration of Belénis perceived as a challenge to the legitimacy of middle-class values.

Firstly, Belén plays the role of an unpredictable, unruly character: she usually interrupts her co-workers and the host, chews gum while she is talking, goes on and off the set whenever she wants (to get water or food). Secondly, her lack of education is also underlined. Jorge Javier Vázquez usually asks her questions on 'general culture' that he knows she won't be able to answer: to locate some country on a map, or name its capital, to explain the main traits of different periods in human history or even to say something in English. Sometimes the programme devotes considerable time to such 'cultural tests'. Finally, Belén is conveyed as 'authentic', a trait traditionally also related to working-classness (Skeggs 2004, p. 105-107). She is appreciated for being 'herself', for not being capable of constructing a public self different from her private self ${ }^{18}$ and displaying uncontrollable, strong emotions (understood as 'real' and 'sincere', see Ellis 2009).

The challenge represented by Sálvame to social and cultural norms and hierarchies also has to do with the space assigned to popular culture in the Spanish public sphere. Sálvame has an ironic, self-conscious discourse regarding its assigned social space and the criticism that it arouses in the wider media. Nevertheless, Sálvame usually responds to and challenges such criticisms. 
One of the most interesting responses was acted out in 2010, when Sálvame played with the idea of entering the political arena (i.e. the serious, masculine public sphere). The programme's host and collaborators started to talk about politics and Belén Esteban started making overtly political comments that were cheered by the audience: on education, public health, the Spanish government's management of the economic crisis, etc. Moreover, the documentary La princesa del pueblo ('The people's princess') ${ }^{19}$ (Telecinco 2010) presented the results of a survey according to which if Belén Esteban founded a political party and ran in the Spanish elections, her party would enter congress and achieve 5 seats. Belén even 'threatened' to create an actual political party if Spanish politicians didn't do their job properly.

By doing this, Sálvame tried to go beyond its assigned social space and enter an arena where the programme 'does not belong'. At the same time, this was an attempt to attack and mock Spanish politicians. For example, the documentary claimed that Belén was not so different from some Spanish politicians who were also populists or didn't have an education.

In fact, the programme aligned itself with (and exploited) the current debates on Spanish democracy falling into disrepute and political parties' failure to be representative. This can be linked to the debates regarding popular culture and politics explained by Liesbet van Zoonen (2005) and John Street (2004, 2012). By proposing Belén Esteban as a politician, Sálvame was indirectly proposing a new definition of representativeness, according to which politicians should be 'like us' and speak and behave in ways that 'appeal to sections of the public who traditionally feel intimidated by the language and discourses of politics' (Coleman quoted by Street 2004, p. 442).

Belén's political claims are also a challenge to traditional gender roles and established boundaries between the public and private sphere. As I said at the beginning 
of this section, she embodies traditional feminine roles related to the private sphere. Nonetheless, she claims her right to give her opinion about the political and economic situation and to play a role in the public sphere. Moreover, she underlines the significance of her personal experience (and her friends' and family's experience) to interpret these public issues.

Nevertheless, Sálvame also sets limits and restrains Belén Esteban as a celebrity. This is the very ambivalence that John Fiske (1989) identified as an essential trait of popular culture, which is always contradictory since it conveys both the values of the dominant and subordinate classes. The programme also includes the disciplining gaze of the middle class, embodied by the host. Belén is usually mocked by Jorge Javier Vázquez and in the programme's features. By doing so, the audiovisual text encourages the viewer to look on her in both amusement and disgust.

A good example of this is Sálvame Deluxe's section Los ojos de Belén ('Belén's eyes'). This is a 'lifestyle swap' segment in which Belén gets to know other people and their real situations: she lived and worked with a shepherd and with the proprietors of a restaurant in Asturias (08/06/2012), met some people who worked in the sex industry (12/05/2012) and lived with a gypsy family (01/06/2012). These features are characterised by an ironic tone and Belén is made fun of through the voiceover commentaries, the music and the editing. For example, her lack of abilities is usually underlined: in one episode she is not able to dance flamenco, in another she cannot milk a sheep, etc. Actually, we could say that in Los ojos de Belén she is expected to do so many different things that she has never done before that she is bound to fail. This is even more striking in the episode broadcast on 25/05/2012. In this episode, she tried to help two women: one that had been the victim of medical malpractice regarding a plastic surgery operation, and another whose ex-husband wasn't paying her any 
alimony. But Belén didn't achieve any of her objectives, instead being portrayed as an unsuccessful would-be hero. Here again, her lack of abilities is underlined and she is portrayed as powerless, which places her at the antipodes of 'proper' stars, who are usually represented by the media as powerful individuals that can have a positive impact on reality through projects involving charity and advocacy.

This construction of Belén as a 'powerless' celebrity gained momentum over the last months prior to her temporary retirement. She tried to redefine her role in the programme, claiming that she was tired of having to talk about her private life every day and that she could take on other functions in the programme. In her last appearance in Sálvame Deluxe (04/04/2013) she began the interview with these revealing words:

I'd like to explain something. (...) Although I have been interviewed several times and I have earned a lot of money because of this... (...) I'm talked about in Sálvame diario every day, even if I am not on the set. Some weeks Sálvame Deluxe's writers and producers don't have any guest for the programme (...). I'm sat here today because my programme needs me, as I have done so many times in the past. But I want things to change because I'm not feeling well.

Belén here manifests how tired she is of being asked to explain every aspect of her private life on Sálvame. Confession is a central element of celebrity culture, and celebrities 'rely on the confessional to authenticate, validate, humanise, resurrect, extend and enrich their star and celebrity identities' (Redmond 2008, p. 109-110). In our therapeutic culture this is usually conveyed as rewarding, healing and liberating, although of course Foucault foregrounded how confession always takes places within relationships of power (see Dovey 2000, p.105-108). Actually, in Spain famosillos usually 'have to' submit to harsh and humiliating questions in order to gain visibility and/or money, with arguably less capacity to control their public image than 'true stars'. Above, Belén presents confession as a burden, and explicitly foregrounds what she sees 
as the lack of agency inherent in her role as a confessional celebrity.

As part of this power struggle, in her last appearance before leaving the programme, Belén mentioned Lydia Lozano's husband (she is one of Sálvame's journalists, whose private life is almost never talked about). By doing this, she demanded equal treatment between her and her co-workers and she did this in front of the cameras. However, although to some extent Sálvame blurs the hierarchies and boundaries between journalists and famosillos, Belén's action was seen as a provocation that transgressed this game's limits:

María Patiño: There are some game rules [to the programme] here (...). There are some people here that are well-known for their profession and others for their private life and it must be clear where every one of us is situated. And if you don't like it, you should leave the programme.

Jorge: (...) I think that what she [Belén] has done to Lydia is brutal (...). It is not right that when we interview her, we are scared that she may ask back 'and what about you?' If we let this happen we would cross a boundary and we would be in the interviewee's place. (...) I don't show my private life, I don't deserve this... I do interviews and I don't have to be treated like you [Belén] because (...) we are not on the same level.

Here, Belén is condemned for breaking the cultural rules of the interview, given that 'interviews are asymmetrical or unequal verbal exchanges' in which 'the interviewer can ask questions of the interviewee, but the interviewee (...) cannot ask similar questions of the professional interviewer' (Bell and Van Leeuwen 1994, p. 224). In doing so, Belén is trying to question the programme's hierarchies, as well as celebrity culture hierarchies. But Sálvame in this case refuses to give her more power and agency, restraining her to the role of famosilla. 


\section{Knowing one's place. Final remarks and conclusions}

The findings of this paper point to a significant amount of shared elements between British and Spanish contemporary celebrity culture and working-class stereotypes. There are striking similarities between the discourses of disgust aroused by Belén Esteban and those identified in the UK against working-class female celebrities. Consequently, it can be argued that also in Spain the 'celebrity can be constructed as a form of disciplinary regime rather than a celebration of individual greatness' (Holmes 2009). The celebrity is used to reinforce social and cultural norms and boundaries, as well as to stigmatise working-class women, represented as undeserving celebrities or as an ignorant, senseless crowd. Belén Esteban functions as a figure that synthesises everything that is wrong in Spanish social, cultural and political spheres.

For Gareth Palmer, these celebrities 'provide cautionary messages for ordinary people' (Palmer 2004, p. 51); they serve as a reminder that 'while there is the potential for ordinary people to "make it", this potential is only offered through a strict framework of limited roles, of which the boundaries are fiercely guarded' (Palmer 2004, p. 49). This is also the case with Belén Esteban and other Spanish famosillos. The debate about Belén's agency within Sálvame shows how difficult it is for famosillos to change their role within celebrity culture. They are restrained in a position where they are mocked, looked upon in contempt and 'forced' to confess. And although it can be argued that Belén is not entirely powerless, since she has the opportunity to address millions of viewers on a daily basis, it is also true that the roles she is allowed to play are limited.

Moreover, her life's narrative is constructed upon a contrast between a happy life as a working-class child and a life full of troubles as a mature celebrity (conflicts with Jesús and his family, drug addiction and divorce). This can easily be read as a 
consequence of being in a place where she does not belong: a cautionary tale against leaving one's social space.

Anita Biressi and Heather Nunn claim that even though these celebrities may experience social and economical ascent, they must maintain some symbolic markers of their class origins, 'a hidden essence or "true" working-class identity concealed beneath the "glitz"” (Biressi and Nunn 2005, p. 146, see also Holmes 2009). This requirement limits the possibility for true social mobility: within this paradigm, the working-classes are never fully allowed to ascend.

Belén Esteban's public image is also constructed mainly upon an ostensible resistance to upward social mobility. Actually, any indication of it endangers her celebrity image: for example, in her last appearances in Sálvame her co-workers accused her of being arrogant, since she was demanding greater power and capacity to act within the programme that she 'did not deserve', and her nickname 'the people's princess' (that points unequivocally to upward mobility) was also regularly mocked.

Nevertheless Belén's resistance to glamour and glitz can also be seen as way of playing out some sort of 'identity politics'. This is a Spanish specificity: class is explicitly mentioned, and the politics entangled in the emergence of working-class celebrities are less concealed. In her TV appearances, Belén claims a distinct social identity as a working-class woman and demands a visible place in the public sphere. But it can be argued that by using a carnivalesque strategy to ascribe value to workingclassness, underlining the very traits regularly used by middle-classes to despise them, this kind of identity politics fails and restrains her to a subordinate position.

\section{Acknowledgments}

I would like to thank Dr. Su Holmes for her help and advice during the writing of this paper. 


\section{Bibliography}

Alarcón, E., 2010. Re: Sorpresas te da la vida. Escrito en un instante. (online).

Available from: http://xn--antoniomuozmolina-nxb.es/2010/12/sorpresas-te-dala-vida/\#comment-4345 (Accessed 18 June 2013).

Bell, P. and Van Leeuwen, T., 1994. The media interview. Confession, contest, conversation. Kensington: University of South Wales Press.

Bennett, J. and Holmes, S., 2010. The 'place' of television in celebrity studies. Celebrity Studies, 1 (1), 65-80.

Biressi, A. and Nunn, H., 2005. Reality TV. Realism and revelation. London: Wallflower Press.

Bourdieu, P., 1984. Distinction. A social critique of the judgement of taste. Cambridge: Harvard University Press.

Cáceres, M.D., 2000, La crónica rosa en televisión o el espectáculo de la intimidad. Cuadernos de Información y Comunicación, 5, 277-290.

Dovey, J., 2001. Freakshow. London: Pluto Press.

Dyer, R., 1986. Heavently bodies. Film stars and society. London: MacMillan Press.

Dyer, R., 1998. Stars. London: Palgrave Macmillan.

Ellis, J., 2009. The performance on television of sincerely felt emotions. The ANNALS of the American Academy of Political and Social Science, 625, 103-115.

Elvira, 2010. Re: Sorpresas te da la vida. Escrito en un instante. (online). Available from: http://xn--antoniomuozmolina-nxb.es/2010/12/sorpresas-te-da-lavida/\#comment-4337 (Accessed 18 June 2013).

Fairclough, K., 2012. Nothing less than perfect. Female celebrity, ageing and hyperscrutiny in the gossip industry. Celebrity Studies, 3 (1), 90-103.

Falcón, P., 1998. El imperio rosa. Poder e influencia de la prensa del corazón. Barcelona: CIMS.

Fiske, J., 1989. Understanding popular culture. London: Routledge.

Galaz, M., 2010. El reality de lo crudo. El País, 14 March. (online). Available from: http://elpais.com/diario/2010/03/14/agenda/1268521201_850215.html (Accessed 18 June 2013).

Gamson, J., 1994. Claims to fame. Celebrity in contemporary America. Berkeley: University of California Press. 
Gómez Mompart, J.L., 1992. Medio siglo de prensa del corazón en España (19401990). Anàlisi, 14, 47-59.

Holmes, S., 2004. 'All you've got to worry about is the task, having a cup of tea, and doing a bit of sunbathing'. Approaching celebrity in Big Brother. In: S. Holmes and D. Jermyn, eds. Understanding reality television. London: Routledge, 111135.

Holmes, S., 2005. 'Off-guard, unkempt, unready'? Deconstructing contemporary celebrity in heat magazine. Continuum. Journal of Media \& Cultural Studies, 19 (1), 21-38.

Holmes, S., 2009. 'Jade's back, and this time she's famous'. Narratives of celebrity in the Celebrity Big Brother race row'. Entertainment and Sports Law Journal, 7 (1). (online). Available from: http://go.warwick.ac.uk/eslj/issues/volume7/number1/holmes/ (Accessed 18 June 2013).

Lamuedra, M., 2005. Formatos híbridos y melodrama en televisión. El caso de Belén Esteban como heroína post-moderna. Estudio de recepción. Estudios sobre el Mensaje Periodístico, 11, 349-374.

Lamuedra, M., 2007. Las historias de famosos en la sociedad mediática. ¿Por qué tantos, por qué ahora?. Huelva: Diputación de Huelva.

Lawler, S., 1999. 'Getting out and getting away'. Women's narratives of class mobility. Feminist Review, 63, 3-24.

Lawler, S., 2004. Rules of engagement. Habitus, power and resistance. The Sociological review, 52 (s2), 110-128.

Lawler, S., 2005. Disgusted subjects. The making of middle class identities. The Sociological review, 53 (3), 429-446.

Lawler, S., 2008. Identity. Sociological perspectives. Cambridge: Polity.

Marshall, P.D., 1997. Celebrity and power. Fame in contemporary culture. Minneapolis: University of Minnesota Press.

Mercado Sáez, M., 1999. La información del corazón en televisión. Revista Latina de Comunicación Social, 21. (online). Available from: http://www.ull.es/publicaciones/latina/a1999dse/49va2.htm (Accessed 18 June 2013).Moseley, R., 2001. “"Real lads do cook... but some things are still hard to talk about". The gendering of 8-9 factual entertainment on British television'. European Journal of Cultural Studies, 4(1), 32-39. 
Muñoz Molina, A., 2010. Sorpresas te da la vida. Escrito en un instante. (online).

Available from: http://xn--antoniomuozmolina-nxb.es/2010/12/sorpresas-te-dala-vida/ (Accessed 18 June 2013).

Negra, D. and Holmes, S., 2008. Introduction. Genders, 48. (online). Available from: http://www.genders.org/g48/g48_negraholmes.html (Accessed 18 June 2013).

Nofre, J., 2008. L'agenda cultural oculta. Una deconstrucció de l'oci nocturn de Barcelona i els seus suburbis. Thesis (PhD). Universitat de Barcelona.

Palmer, G., 2005. The undead. Life on the D-List. Westminster Papers on Communication and Culture, 2 (2), 37-53.

Pérez Oliva, M., 2011. Un nuevo triunfo para Belén Esteban. El País, 02 January. (online). Available from:

http://elpais.com/diario/2011/01/02/opinion/1293922805_850215.html (Accessed 18 June 2013).Quesada, L., 2010. Re: Sorpresas te da la vida. Escrito en un instante. (online). Available from: http://xn--antoniomuozmolinanxb.es/2010/12/sorpresas-te-da-la-vida/\#comment-4326/ (Accessed 18 June 2013).

Ramoneda, J., 2010. La construcción cultural del fascismo. El País, 17 November. (online). Available from: http://elpais.com/diario/2010/11/17/opinion/1289948412_850215.html (Accessed 18 June 2013).

Redmond, S., 2008. The star and celebrity confessional. Social Semiotics, 18 (2), 109114.

Rojek, C., 2001. Celebrity. London: Reaktion Books.

Skeggs, B., 2004. Class, self, culture. London: Routledge.

Street, J., 2004. Celebrity politicians. Popular culture and political representation. The British Journal of Politics \& International Relations, 6 (4), 435-452.

Street, J., 2012. Do celebrity politics and celebrity politicians matter? The British Journal of Politics \& International Relations, 14 (3), 346-356.

Thomas, L., 2011. 'Alternative realities. Downshifting narratives in contemporary lifestyle television'. In: S. Binkley and J. Littler, eds. Cultural Studies and anticonsumerism. London: Routledge, p. 162-181.

Tyler, I., 2008. 'Chuv mum, chuv scum'. Class disgust in contemporary Britain. Feminist Media Studies, 8 (1), 17-34. 
Tyler, I. and Bennett, B., 2010. Celebrity chav. Fame, femininity and social class'. European Journal of Cultural Studies, 13 (3), 375-393.

Van Zoonen, L., 2005. Entertaining the citizen. When politics and popular culture converge. Lanham: Rowman \& Littlefield Publishers.

Vertele , 2012. ¿Cuánto ha cobrado Belén Esteban por confesar sus adiciones en TV? Vertele, 1 december (online). Available from: http://www.vertele.com/noticias/\%C2\%BFcuanto-ha-cobrado-belen-estebanpor-confesar-sus-adicciones-en-tv/\#Comentarios (Accessed 12 July 2013).

\section{Notes on contributor}

Dr. Mercè Oliva is a Visiting Lecturer at the Department of Communication at Universitat Pompeu Fabra (Barcelona, Spain). She is the author of the book Telerrealidad, Disciplina e Identidad. Los makeover shows en España (Ed. UOC, 2013). She has also published articles in journals such as Communication \& Society and Comunicar. Her key research interests are celebrity culture, reality TV, popular culture and videogames.

${ }^{1}$ Chris Rojek has called this kind of celebrity 'attributed', i.e. 'the result of the concentrated representation of an individual as noteworthy or exceptional by cultural intermediaries' (Rojek 2001, p. 18), as opposed to 'achieved celebrity', which 'derives from the perceived accomplishments of the individual in open competition' and 'ascribed celebrity', related to lineage (Rojek 2001, p. 17-18).

${ }^{2}$ Belén Esteban appeared for the first time on the cover of a celebrity gossip magazine in January 1999, when she made her pregnancy public on the cover of ;Hola!.

${ }^{3}$ In June 2000, January 2004, November 2005 and June 2012.

${ }^{4}$ These magazines are very similar to heat (see Holmes 2005).

${ }^{5}$ Nevertheless, it has been claimed that there is nothing new about them. See Bennett and Holmes (2010) and Holmes (2004, 2005) for an analysis of the British context.

${ }^{6}$ For example, in the documentary La Princesa del Pueblo (Telecinco 2010).

${ }^{7}$ Ugly, uncultivated and common.

${ }^{8}$ This animalisation reminds us the comparison of Jade Goody with a pig in the British media (Holmes 2009). 
${ }^{9}$ For example:

http://www.eljueves.es/2010/01/01/ano_mierda_menos_para_belen_esteban.html and http://www.eljueves.es/2009/09/23/espana_tiene_claras_sus_prioridades.html

${ }^{10}$ Vertele is a popular news website devoted to Spanish television.

${ }^{11}$ For example, Homo Zapping (Antena 3 2003-2007) and Sé Lo Que Hicisteis (La Sexta 20062011).

${ }^{12}$ Similarly, Tyler (2008, p. 23) in her analysis of the media construction of the chav says that 'in a perverse appropriation of identity politics, journalists (...) claim middle-class identity as a site of injury and oppression (...) and thus actively defend (and reproduce) upper middle-class entitlement'.

${ }^{13}$ A Spanish writer and member of the Royal Academy of the Spanish Language.

${ }^{14}$ Peregrina's work mimics the Romanesque fresco of the Church of Santa Maria's apse, in Taüll (Spain).

${ }^{15}$ Interestingly, in informal Spanish 'to gossip' is also called marujear.

${ }^{16}$ Similar strategies have been identified by Jordi Nofre (2008, p. 223-245) regarding Spanish working-class youth cultures.

${ }^{17}$ John Fiske argues that popular culture shares a number of traits with the world of carnival. Both carnivalesque texts and texts from popular culture invert social rules and 'build a world upside down, one structured according to the logic of "inside out" that provides "a parody of the extracarnival life"' (Fiske 1982, p. 82).

${ }^{18}$ This continuity between the on/off screen self is also a characteristic feature of television personalities and Reality TV celebrities. See Holmes (2004, 2005, 2009).

${ }^{19}$ This nickname, borrowed from Princess Diana, was introduced by Sálvame in 2010. This is a good example of the ironic and self-conscious character of Spanish contemporary celebrity culture: by calling Belén 'la princesa del pueblo' she is linked to royalty (one of the most traditional forms of celebrity) and, at the same time, the differences between their cultural capital are underlined. 